\title{
Optogenetic modulation in stroke recovery
}

\author{
*Arjun V. Pendharkar, MD, Sabrina L. Levy, BS, Allen L. Ho, MD, Eric S. Sussman, MD, \\ Michelle Y. Cheng, PhD, and Gary K. Steinberg, MD, PhD
}

\author{
Department of Neurosurgery, Stanford University School of Medicine, Stanford, California
}

\begin{abstract}
Stroke is one of the leading contributors to morbidity, mortality, and health care costs in the United States. Although several preclinical strategies have shown promise in the laboratory, few have succeeded in the clinical setting. Optogenetics represents a promising molecular tool, which enables highly specific circuit-level neuromodulation. Here, the conceptual background and preclinical body of evidence for optogenetics are reviewed, and translational considerations in stroke recovery are discussed.

http://thejns.org/doi/abs/10.3171/2016.2.FOCUS163
\end{abstract}

KEY WORDS optogenetics; DREADD; designer receptor exclusively activated by designer drugs; stroke; ischemia; neuroregeneration; plasticity

$\mathrm{S}$ TROKE is the leading cause of long-term disability in the United States, ${ }^{67}$ with a projected prevalence of 3.4 million by $2030^{67}$ and an annual cost of approximately $\$ 34$ billion. ${ }^{67}$ Treatment options include intravenous tissue plasminogen activator and endovascular thrombolysis but are limited to ischemic stroke and a narrow administration window. From a basic science perspective, numerous experimental therapies have shown success in the laboratory, yet none have successfully reached the clinic. ${ }^{107}$

Neuroprotective strategies, including glutamate receptor antagonists, ion channel regulators, free radical scavengers, and antiinflammatory compounds, have shown promise in preclinical models but have failed in human studies. ${ }^{18,63}$ Stem cell-based strategies represent another promising therapeutic avenue, but are pending FDA approval. Transcranial stimulations such as transcranial direct current stimulation and transcranial magnetic stimulation have also produced some preliminary success., ${ }^{7,45,72,96}$

Optogenetics is an emerging method for studying central nervous system function. Genetically encoded channels and receptors that are responsive to single-wavelength light sources are used to allow optical control of the neural circuits. This technology can be used to target specific cell populations and restore central nervous system function. Here, we review the conceptual background and preclinical body of evidence for optogenetics and discuss translational considerations in stroke recovery.

\section{Optogenetics}

Optogenetics uses light-responsive cellular elements to produce stimulation, inhibition, and silencing of neurons. ${ }^{26,29,64,66,98}$ One major advantage of this tool is the rapid kinetics that lead to precise temporal and geographic targeting. ${ }^{31,102}$ When a photon hits naturally occurring opsins, the molecules undergo a conformational change. Channelrhodopsin, the first photo-responsive channel to be widely implemented, is a light-responsive, cation-selective ion channel found in Chlamydomonas reinhardtii. ${ }^{9,69,70} \mathrm{In}$ the case of channelrhodopsin-2, a blue photon induces a conformational change from all-trans to the 13-cis-retinal conformer, which opens a cation pore in the ionotropic ion channel that directly leads to depolarization and an ensuing action potential., ${ }^{9}, 103$

Several additional optogenetic channels have been developed to allow further modulation (Table 1). Halorhodopsin, which is found in the bacterium Natronobacterium

ABBREVIATIONS ArchT = archaerhodopsin; BDNF = brain-derived neurotrophic factor; CAP-23 = cytoskeleton-associated protein 23; CNO = clozapine-N-oxide; DREADD $=$ designer receptor exclusively activated by designer drugs; EGF = epidermal growth factor; FGF-2 = basic fibroblast growth factor 2; GABA = $\gamma$-aminobutyric acid; GAP43 = growth-associated protein 43; GDF10 = growth differentiation factor 10; GDNF = glial cell line-derived neurotrophic factor; IGF1 = insulin-like growth factor 1; iM1 = ipsilesional primary motor cortex; MARCKS = myristoylated alanine-rich protein kinase $\mathrm{C}$ substrate; NGF = nerve growth factor; NTF3 = neurotrophin-3; WGA = wheat germ agglutinin.

SUBMITTED January 1, 2016. ACCEPTED February 16, 2016.

INCLUDE WHEN CITING DOI: 10.3171/2016.2.FOCUS163.

* Dr. Pendharkar and Ms. Levy contributed equally to this work. 
TABLE 1. Survey of widely used optogenetic tools

\begin{tabular}{|c|c|c|c|c|}
\hline Tool & Description & Advantages & Limitations & Select References \\
\hline $\begin{array}{l}\text { Channelrhodopsin-2 } \\
\text { (Chlamydomonas } \\
\text { reinhardtii) }\end{array}$ & $\begin{array}{l}\text { Excitatory; cation channel } \\
\text { responsive to blue light }\end{array}$ & $\begin{array}{l}\text { Millisecond \& temporal precision; } \\
\text { single-gene basis facilitates } \\
\text { use w/ other genetic tools }\end{array}$ & $\begin{array}{l}\text { Light scattering in tissue can } \\
\text { lead to imprecise activation }\end{array}$ & $\begin{array}{l}\text { Boyden et al., 2005; } \\
\text { Cheng et al., } 2015\end{array}$ \\
\hline $\begin{array}{l}\text { Halorhodopsin (Natro- } \\
\text { nomonas pharaonis) }\end{array}$ & $\begin{array}{l}\text { Inhibitory; chloride channel } \\
\text { responsive to yellow light }\end{array}$ & $\begin{array}{l}\text { Millisecond \& temporal precision; } \\
\text { single-gene basis facilitates } \\
\text { use w/ other genetic tools }\end{array}$ & $\begin{array}{l}\text { Chloride channels enter into } \\
\text { inactivation phase \& con- } \\
\text { stitutive inhibition requires } \\
\text { exposing tissue to light for } \\
\text { long periods \& can lead to } \\
\text { heat damage; unsuited for } \\
\text { long-scale or high-quantity } \\
\text { silencing }\end{array}$ & $\begin{array}{l}\text { Nagel et al., } 2003 \\
\text { Kandori et al., } \\
2015\end{array}$ \\
\hline $\begin{array}{l}\text { Archaerhodopsin (Haloru- } \\
\quad \text { brum sodomense) }\end{array}$ & $\begin{array}{l}\text { Inhibitory; proton pump si- } \\
\text { lences neurons in response } \\
\text { to yellow light }\end{array}$ & $\begin{array}{l}\text { Spontaneously recovers from } \\
\text { light-driven inactivation; good } \\
\text { for large-scale silencing }\end{array}$ & $\begin{array}{l}\text { Light scattering in tissue can } \\
\text { lead to imprecise activation }\end{array}$ & Chow et al., 2010 \\
\hline $\begin{array}{l}\text { Mac (Leptosphaeria } \\
\text { maculans) }\end{array}$ & $\begin{array}{l}\text { Inhibitory; proton pump si- } \\
\text { lences neurons in response } \\
\text { to blue-green light }\end{array}$ & $\begin{array}{l}\text { Responds to a different color } \\
\text { light; can be used w/ another } \\
\text { channel for the dual control of } \\
2 \text { separate populations }\end{array}$ & $\begin{array}{l}\text { Light scattering in tissue can } \\
\text { lead to imprecise activation }\end{array}$ & Waschuk et al., 2005 \\
\hline LiGluR & $\begin{array}{l}\text { Light-activated ionotropic } \\
\text { glutamate receptor via } \\
\text { photoswitchable ligands; } \\
\text { agonized \& antagonized } \\
\text { variants available }\end{array}$ & $\begin{array}{l}\text { Light control of GPCR enables } \\
\text { dissection of neurocircuitry; } \\
\text { provides more nuanced } \\
\text { control }\end{array}$ & $\begin{array}{l}\text { Requires separate addition of } \\
\text { MAG photoswitch solution } \\
\text { prior to activation }\end{array}$ & Gorostiza et al., 2007 \\
\hline LimGlur & $\begin{array}{l}\text { Light-activated metabotropic } \\
\text { glutamate receptor via } \\
\text { photoswitchable ligands }\end{array}$ & $\begin{array}{l}\text { Light control of metabotropic } \\
\text { GPCR enables dissection of } \\
\text { messenger systems; provides } \\
\text { more nuanced control }\end{array}$ & $\begin{array}{l}\text { Requires separate addition of } \\
\text { MAG photoswitch solution } \\
\text { prior to activation }\end{array}$ & Levitz et al., 2013 \\
\hline DREADDs & $\begin{array}{l}\text { Modified muscarinic receptors } \\
\text { respond to biologically inert } \\
\text { CNO }\end{array}$ & $\begin{array}{l}\text { Circumvents need for a light } \\
\text { source }\end{array}$ & $\begin{array}{l}\text { Systemic administration of } \\
\text { inert CNO agonist depends } \\
\text { on metabolism for "off" } \\
\text { switch; less temporally pre- } \\
\text { cise than optical controls }\end{array}$ & Wahl et al., 2014 \\
\hline
\end{tabular}

GPCR = G protein-coupled receptor; LiGluR = light-activated ionotropic glutamate receptor; LimGlur = light-activated metabotropic glutamate receptor.

pharaonis, is a chloride channel that responds to a green/ yellow light and enables the inhibition of neurons. ${ }^{48,70,105}$ Archaerhodopsin (ArchT) is another inhibitory bacteriorhodopsin and functions as an outward proton pump. ${ }^{21}$ The differences in kinetics between halorhodopsin and ArchT provide an example of the complexity of the optogenetics platform: the former recovers slowly, while ArchT recovers spontaneously after light-induced inactivation. Additional light-responsive glutamate receptors have been engineered using photosensitive ligands, enabling investigation of synaptic transmission mechanisms as well as an emerging treatment strategy for retinitis pigmentosa. ${ }^{32,58,80}$

From an experimental perspective, our group has recently reviewed the technical considerations of using optogenetic technology in the laboratory. Briefly, imaging and stimulation can be achieved using 2-photon microscopy via cranial windows. Rodents can be awake or anesthetized, and several groups have used integrated microscopy and fiberoptics to measure and record circuit responses in experimental models. Thermal tissue stimulation must be considered when stimulating with light and may confound results..$^{17}$
The strength of the optogenetic platform lies in the temporal and geographic precision of the system. Millisecond-scale responses have been demonstrated using photon induction, ,939,104 and the effect begins and ends immediately. This is in stark comparison with traditional electrical stimulation, which produces artifactual or unwanted effects in surrounding tissues. Delivery platforms include viral injection that utilizes a host of vectors and constructs, as well as transgenic animals. ${ }^{31,102}$ Viral injections have the benefit of limiting optogenetic expression to a specific geographic region, depending on the amount of virus injected and promoter specificity (Table 2).

Optogenetics in combination with targeted genetic strategies creates the possibility of the highly specialized targeting of the cells that are linked functionally, structurally, by identity, or even by seemingly idiosyncratic synchronized activity. A proposed therapeutic modality would benefit from geographic and temporal specificity.

\section{Proposed Targets for Stroke Recovery}

Optogenetics may be applied toward recovery after 
TABLE 2. Cell type-specific promoters for genetic targeting

\begin{tabular}{|c|c|c|}
\hline Cell Population & Promoter & Selected References \\
\hline Pan-neuronal & Synapsin, hThy1 & $\begin{array}{l}\text { Kügler et al., 2003; } \\
\text { Diester et al., } 2011\end{array}$ \\
\hline Glutamatergic (excitatory) & CaMKII & Rongo et al., 1999 \\
\hline GABAergic (inhibitory) & VGAT & Zhao et al., 2011 \\
\hline Dopaminergic & $\mathrm{THp}$ & Oh et al., 2009 \\
\hline Serotonergic & $\mathrm{TPH}$ & Zhao et al., 2011 \\
\hline Cholinergic & ChAT & Zhao et al., 2011 \\
\hline Purkinje cells & L7 & Tsubota et al., 2011 \\
\hline Oligodendrocytes & MBP & Lawlor et al., 2009 \\
\hline Astrocytes & gfaABC1D & Lee et al., 2008 \\
\hline $\begin{array}{l}\text { Activity-dependent promot- } \\
\text { ers }\end{array}$ & Fos, Arc & Guenthner et al., 2013 \\
\hline
\end{tabular}

CaMKII = calcium- and calmodulin-dependent protein kinase type II; ChAT = choline acetyltransferase; hThy 1 = human thymocyte-1; MBP = myelin basic protein; $\mathrm{THp}=$ tyrosine hydroxylase promoter; TPH = tryptophan hydroxylase promoter; VGAT = vesicular GABA transporter.

stroke at the hemispheric level, within specific circuits, or targeted to cells promoting plasticity.

\section{Disinhibition Hypothesis: Excitation and Inhibition Following Stroke}

The disinhibition hypothesis postulates that each cerebral hemisphere inhibits the activity of the other ${ }^{87,101}$ and mutual inhibition leads to a balanced baseline activity level. In stroke, overactivation of the contralateral hemisphere perpetuates ipsilesional damage, and a positive feedback loop develops that leads to progressive functional deterioration. ${ }^{37}$ This concept carries significance for timing rehabilitation, and animal studies show that immediate rehabilitation following stroke can prohibit long-term recovery and lead to permanent damage in the penumbra. ${ }^{52,53}$ Early intervention has also been linked to increased cell death in the penumbra. ${ }^{30,81}$ A Phase III trial-A Very Early Rehabilitation Trial (AVERT) - found that rehabilitation beginning 24 hours after stroke leads to a higher likelihood of worse clinical outcomes at the 90-day poststroke time point. ${ }^{5}$

From a mechanistic standpoint, $\gamma$-aminobutyric acid (GABA) plays a critical role in poststroke brain repair. There is the downregulation of the GABAergic pathways, leaving the ipsilesional hemisphere ${ }^{2,79}$ and increased GABA receptors in the ischemic core ${ }^{85,86} \mathrm{GABA}$ signaling exists in both tonic (extrasynaptic) and phasic (synaptic) states. The former is increased after stroke in contrast to phasic GABA signaling, which is decreased. Reducing tonic GABAergic inhibitory pathways using a GABA receptor antagonist has produced functional recovery in rodent stroke models, implicating perilesional cortex inhibition as a major mechanism..$^{22}$ In contrast to tonic signaling, which is largely thought to be detrimental, our group recently demonstrated that increasing phasic GABA signaling after stroke produces a functional benefit in experimental models. ${ }^{43}$ From these findings, 3 proposed targets have emerged as optogenetic therapies for stroke:
1) perilesional and global hyperexcitability immediately following stroke: ${ }^{71,85}$ 2) decreased ipsilesional inhibitory postsynaptic potentials, ${ }^{62}$ and 3) sustained contralesional hyperexcitability. ${ }^{65,85}$

\section{Optogenetic Stimulation and Stroke Recovery}

Given the body of evidence supporting imbalanced inhibition following ischemia and reperfusion, our group has recently shown that targeted optogenetic stimulation of the ipsilesional primary motor cortex (iM1) produces functional recovery in rodent stroke models. ${ }^{19}$ Transgenic Thy1-Channelrhodopsin-2 mice were implanted with an optical fiber over the iM1. In response to targeted iM1 stimulation, the cells in the perilesional and contralesional hemisphere fired reliably and specifically, as verified by electrophysiology recordings. Mice underwent three 1-minute stimulations per day from poststroke Days 5 to 14. Behavior tests showed that iM1-stimulated mice exhibited functional behavioral recovery at Days 10 and 14 following an experimental stroke model. Biochemically, the increased levels of the plasticity markers, including activity-dependent neurotrophins brain-derived neurotrophic factor (BDNF), nerve growth factor (NGF), and neurotrophin-3 (NTF3), were observed, as well as higher GAP-43 plasticity marker expression. These data suggest that functional recovery is likely related to plasticity-associated remodeling and provide a proof of concept that optogenetic neuronal stimulation can enhance recovery after stroke.

\section{Poststroke Plasticity State and Growth Factor Release}

Another therapeutic strategy involves modulating the endogenous regenerative response after stroke. There are several promising targets. The plasticity markers growthassociated protein 43 (GAP-43), cytoskeleton-associated protein 23 (CAP-23), and myristoylated alanine-rich protein kinase $\mathrm{C}$ substrate (MARCKS) are upregulated in the postischemic milieu. ${ }^{12,13,68,77}$ Growth differentiation factor 10 (GDF10), a growth factor, has also been implicated in promoting poststroke plasticity, ${ }^{61}$ and upregulation in the perilesional cortex is conserved across species in both in vivo and in vitro studies ${ }^{60}$ Insulin-like growth factor 1 (IGF1) and Nogo receptor complex-1 are involved in cell adhesion, axonal guidance, and cellular architecture modifications. ${ }^{61}$ A neurite inhibitor, Nogo-A, is implicated in inhibiting poststroke axonal sprouting, ${ }^{47}$ and its inhibition mitigates this effect. ${ }^{89,90,99}$ High levels of various growth factors, including BDNF, NGF, NTF3, basic fibroblast growth factor 2 (FGF-2), IGF-1, epidermal growth factor (EGF), and glial cell line-derived neurotrophic factor (GDNF), further characterize the postischemic regenerative environment. ${ }^{19,77}$

Our group has demonstrated that iM1-stimulated mice exhibited an increase in the expression of neurotrophin factors BDNF, NGF and NTF3 in the contralesional motor cortex at poststroke Day 15. Additionally, these changes were absent in stimulated, nonstroke mice. The axonal 
growth protein GAP-43 marker was also upregulated in stimulated mice. ${ }^{19}$ We hypothesize that optogenetic stimulation during the acute postischemic period will help strengthen and rebuild potentially beneficial connections that are degraded during ischemia. New connections that are activated by a selective optogenetic paradigm can recapitulate and bolster an "adolescent critical period" that can help rebuild necessary inhibitory interhemispheric connections and reestablish interhemispheric balance.

Stem cell therapies have shown promise in preclinical studies, and optogenetic modulation may provide an additional strategy for improving outcome. ${ }^{6,24,42}$ Targeted cell migration and the activation of endogenous neurogenesis pathways may be augmented by photomodulation. $6,8,24,33,34,40,42,44,50,74,75,84$ Each of these well-characterized pathways and mechanisms may be targeted using optogenetic stimulation to enhance endogenous mechanisms or exogenously introduced cells and their contribution to functional recovery.

In a recent example, neural stem cells were optogenetically modified to express channelrhodopsin- 2 , then engrafted in vivo. Chronic optogenetic stimulation of the transplanted cells led to the genetic expression of the transcripts involved in neuronal differentiation, axonal sprouting, and synaptic plasticity. The overall inflammatory response was also reduced, and stimulated transplanted rodents demonstrated behavioral improvement compared with controls. ${ }^{23}$

\section{Combination With Genetic Strategies for Improved Precision and Control}

The power of optogenetics lies in the ability to exploit molecular genetic tools to develop cell or circuit specific targets that allow geographic and temporal control. Several well-described cell-specific promoters are outlined in Table 2. For example, driving channelrhodopsin expression under the CaMKII promoter allows for the selective stimulation of excitatory cell circuits. Similarly, expressing halorhodopsin under the somatostatin promoter can induce the specific inhibition of inhibitory circuits. The identification of the promoters associated with elevated activity in neurons, such as c-Fos and p-CREB, are further paving the way for the selective isolation of active circuits. ${ }^{49}$ One recent example of a cell-specific optogenetic strategy involves selective targeting of the excitatory cells in the subthalamic nucleus through lentiviral CaMKII $\alpha$ driven halorhodopsin expression. ${ }^{36}$ More recently, 4 cellspecific channelrhodopsin-2 transgenic mouse lines were generated and characterized to employ VGAT, ChAT, Tph2, and Pvalb promoters for GABAergic, cholinergic, serotonergic, and parvalbumin-expressing neuron specificity. ${ }^{106}$

Perhaps one of the most useful genetic tools for selective circuit-specific control is the 2-component Cre-inducible genetic system. ${ }^{76}$ The Cre enzyme, which is coded for by the Cre recombinase gene, selectively excises LoxP regions. By flanking a STOP codon with LoxP sites upstream of the gene of interest, the selective expression of a gene of interest occurs after the addition of Cre. Cre is delivered using a separate virus (AAV-Cre), conjugation to a neurotracer (i.e., wheat germ agglutinin [WGA]-Cre), or by crossing with another transgenic animal line that expresses Cre. Cell-specific promoters can drive both viral and transgenic Cre, as well. Circuit-level targeting can be achieved by administering Cre that has been conjugated to a retrograde, anterograde, or transsynaptic neural tracer such as the ubiquitously used WGA tracer. ${ }^{59}$ Temporal activation is possible using Cre that has been modified with an estrogen receptor that selectively responds to tamoxifen administration. ${ }^{27,38}$ Finally, Cre-mediated gene expression can be targeted to specific regions using a viral Cre injection.

As optogenetic strategies come to fruition, one major shortcoming will be the need for direct photon delivery in vivo, which may be difficult to apply in the clinical setting. Another emerging chemogenetic strategy may obviate this translational hurdle.

\section{Chemogenetic Manipulation: DREADDs}

Similar to channelrhodopsin, genetically encoded designer receptors exclusively activated by designer drugs (DREADDs) respond selectively to a systemically administered compound (i.e., the role of light in the optogenetic system), resulting in the excitation or silencing of the receptor. The DREADD system involves a genetically expressed $G$ protein-coupled receptor system that is modified to exclusively respond to a biologically inert compound, clozapine $\mathrm{N}$-oxide $(\mathrm{CNO})$, and has no response to endogenous compounds. ${ }^{3,56,92,93,98} \mathrm{CNO}$ is safe and inert to the endogenous system, yet selectively binds to the DREADD receptor to either activate or inhibit the cell. Thus, chemogenetic manipulations are possible with precise selectivity, similar to optogenetics. One recent study used DREADDs to selectively modulate anti-Nogo-A (a growth inhibitory protein implicated in poststroke insult) in the corticospinal tract and elucidate a novel mechanism in postischemic recovery. ${ }^{94}$

\section{Translational Considerations}

The temporal, cell-specific, circuit-specific, and rapid kinetics of optogenetics has brought about significant advances in multiple disease models, including Parkinson's, epilepsy, retinitis pigmentosa, and rhythmic heart disorders. ${ }^{4,10,11,16}$ There are, however, many challenges that must be addressed first, ranging from gene therapy, light delivery technology, and the optimization of stimulation paradigms. ${ }^{20,100}$

Channelrhodopsin-2 has been successfully expressed in human embryonic cells and subsequently differentiated into cardiac cells, which successfully responded to light activation, using mechanical, biochemical, and electrical verification. ${ }^{1}$ The optogenetic toolset can also manipulate nonhuman primate models. ${ }^{25,41,46}$ Lentiviral and adeno-associated viral optogenetic delivery platforms are safe and effective for nonhuman primates. Viral transfection localizes to the injection site and leads to successful inhibition and stimulation in response to optogenetic activation. ${ }^{28}$ ArchT, which is expressed under the CAG promoter, directed neuronal silencing in nonhuman primates on behavioral and histological levels. ${ }^{14}$ Transfection of human 
embryonic stem cells with channelrhodopsin-2 under the excitatory human synapsin promoter, followed by differentiation into neurons, enabled optical control in vitro. ${ }^{97}$ Additionally, lentiviral expression in humans effectively transduces cells with effects that last 1.5 years. ${ }^{88}$ As gene therapy gains more traction and public acceptance, optogenetics and DREADDs will stand at the forefront of the therapeutic methods to be implemented.

Technical innovations are rapidly solving the challenges of regionally precise light delivery for stimulation. Novel bioelectronics employ biocompatible materials, low power requirements, and microscale components. One such cell-scale device measures $50 \times 50 \mu \mathrm{m}$ and integrates micro-light-emitting diodes, wireless powering, and temperature sensors to detect overheating. ${ }^{51}$ Such a system enables implantation at a precise location with minimal light scattering, especially compared with the scattering present in optical fibers, which can be millimeters wide. A similarly pliable wireless optogenetic system delivers light to the cortex for optical neural control.78

DREADD technology is an additional strategy for obviating the need for a light source. The oral administration of CNO, a biologically inert ligand, can replace light delivery. CNO benefits from its blood-brain barrier-permeable properties. ${ }^{82}$ One notable risk in humans is the metabolism of CNO to clozapine, a drug used in schizophrenia that stimulates multiple neural targets, and this effect is not seen in mice. ${ }^{15}$ DREADD activation relies on the pharmacokinetics of $\mathrm{CNO}$, which limits the temporal precision of neural manipulations. Activation is sustained on the order of hours and reduced to the order of minutes for the localized injection of CNO ${ }^{82}$ More recently, an alternative to $\mathrm{CNO}$ has been engineered that uses the pharmacologically inert Salvinorin B. Salvinorin B in conjunction with the $\kappa$-opioid receptor DREADD may provide improved temporal kinetics compared with CNO.92

\section{Conclusions}

Stroke remains a major contributor to morbidity, mortality, and cost in the United States. Although preclinical experimental strategies have been promising, there is a dearth of translatable targeted therapies. Optogenetic and DREADD technologies provide an opportunity for circuit- and cell-specific modulation. Further studies are needed to further bring these treatments to fruition.

\section{References}

1. Abilez OJ, Wong J, Prakash R, Deisseroth K, Zarins CK, Kuhl E: Multiscale computational models for optogenetic control of cardiac function. Biophys J 101:1326-1334, 2011

2. Alicke B, Schwartz-Bloom RD: Rapid down-regulation of GABAA receptors in the gerbil hippocampus following transient cerebral ischemia. J Neurochem 65:2808-2811, 1995

3. Aston-Jones G, Deisseroth K: Recent advances in optogenetics and pharmacogenetics. Brain Res 1511:1-5, 2013

4. Bentley JN, Chestek C, Stacey WC, Patil PG: Optogenetics in epilepsy. Neurosurg Focus 34(6):E4, 2013

5. Bernhardt J, Langhorne P, Lindley RI, Thrift AG, Ellery F, Collier J, et al: Efficacy and safety of very early mobilisa- tion within $24 \mathrm{~h}$ of stroke onset (AVERT): a randomised controlled trial. Lancet 386:46-55, 2015

6. Bliss T, Guzman R, Daadi M, Steinberg GK: Cell transplantation therapy for stroke. Stroke 38 (2 Suppl):817-826, 2007

7. Bolognini N, Pascual-Leone A, Fregni F: Using non-invasive brain stimulation to augment motor training-induced plasticity. J Neuroeng Rehabil 6:8, 2009

8. Borlongan CV, Chopp M, Steinberg GK, Bliss TM, Li Y, Lu M, et al: Potential of stem/progenitor cells in treating stroke: the missing steps in translating cell therapy from laboratory to clinic. Regen Med 3:249-250, 2008

9. Boyden ES, Zhang F, Bamberg E, Nagel G, Deisseroth K: Millisecond-timescale, genetically targeted optical control of neural activity. Nat Neurosci 8:1263-1268, 2005

10. Boyle PM, Entcheva E, Trayanova NA: See the light: can optogenetics restore healthy heartbeats? And, if it can, is it really worth the effort? Expert Rev Cardiovasc Ther 12:17-20, 2014

11. Busskamp V, Picaud S, Sahel JA, Roska B: Optogenetic therapy for retinitis pigmentosa. Gene Ther 19:169-175, 2012

12. Carmichael ST: Brain excitability in stroke: the yin and yang of stroke progression. Arch Neurol 69:161-167, 2012

13. Carmichael ST, Archibeque I, Luke L, Nolan T, Momiy J, Li S: Growth-associated gene expression after stroke: evidence for a growth-promoting region in peri-infarct cortex. Exp Neurol 193:291-311, 2005

14. Cavanaugh J, Monosov IE, McAlonan K, Berman R, Smith MK, Cao V, et al: Optogenetic inactivation modifies monkey visuomotor behavior. Neuron 76:901-907, 2012

15. Chang WH, Lin SK, Lane HY, Wei FC, Hu WH, Lam YW, et al: Reversible metabolism of clozapine and clozapine $\mathrm{N}$-oxide in schizophrenic patients. Prog Neuropsychopharmacol Biol Psychiatry 22:723-739, 1998

16. Chen Y, Xiong M, Zhang SC: Illuminating Parkinson's therapy with optogenetics. Nat Biotechnol 33:149-150, 2015

17. Cheng MY, Aswendt M, Steinberg GK: Optogenetic approaches to target specific neural circuits in post-stroke recovery. Neurotherapeutics [epub ahead of print], 2015

18. Cheng MY, Wang EH, Steinberg GK: Optogenetic approaches to study stroke recovery. ACS Chem Neurosci 5:1144-1145, 2014

19. Cheng MY, Wang EH, Woodson WJ, Wang S, Sun G, Lee AG, et al: Optogenetic neuronal stimulation promotes functional recovery after stroke. Proc Natl Acad Sci U S A 111:12913-12918, 2014

20. Chow BY, Boyden ES: Optogenetics and translational medicine. Sci Transl Med 5:177ps5, 2013

21. Chow BY, Han X, Dobry AS, Qian X, Chuong AS, Li M, et al: High-performance genetically targetable optical neural silencing by light-driven proton pumps. Nature 463:98102,2010

22. Clarkson AN, Huang BS, Macisaac SE, Mody I, Carmichael ST: Reducing excessive GABA-mediated tonic inhibition promotes functional recovery after stroke. Nature 468:305309, 2010

23. Daadi MM, Klausner JQ, Bajar B, Goshen I, Lee-Messer C, Lee SY, et al: Optogenetic stimulation of neural grafts enhances neurotransmission and downregulates the inflammatory response in experimental stroke model. Cell Transplant [epub ahead of print], 2015

24. Daadi MM, Maag AL, Steinberg GK: Adherent self-renewable human embryonic stem cell-derived neural stem cell line: functional engraftment in experimental stroke model. PLoS One 3:e1644, 2008

25. Dai J, Ozden I, Brooks DI, Wagner F, May T, Agha NS, et 
al: Modified toolbox for optogenetics in the nonhuman primate. Neurophotonics 2:031202, 2015

26. Deisseroth K: Optogenetics: 10 years of microbial opsins in neuroscience. Nat Neurosci 18:1213-1225, 2015

27. Deng CX: The use of Cre-loxP technology and inducible systems to generate mouse models of cancer, in Green JE, Ried T (eds): Genetically Engineered Mice for Cancer Research. New York: Springer, 2012, pp 17-36

28. Diester I, Kaufman MT, Mogri M, Pashaie R, Goo W, Yizhar O, et al: An optogenetic toolbox designed for primates. Nat Neurosci 14:387-397, 2011

29. Emiliani V, Cohen AE, Deisseroth K, Häusser M: Alloptical interrogation of neural circuits. J Neurosci 35: 13917-13926, 2015

30. Farrell R, Evans S, Corbett D: Environmental enrichment enhances recovery of function but exacerbates ischemic cell death. Neuroscience 107:585-592, 2001

31. Fenno L, Yizhar O, Deisseroth K: The development and application of optogenetics. Annu Rev Neurosci 34:389412,2011

32. Gaub BM, Berry MH, Holt AE, Isacoff EY, Flannery JG: Optogenetic vision restoration using rhodopsin for enhanced sensitivity. Mol Ther 23:1562-1571, 2015

33. George PM, Steinberg GK: Novel stroke therapeutics: unraveling stroke pathophysiology and its impact on clinical treatments. Neuron 87:297-309, 2015

34. Goings GE, Sahni V, Szele FG: Migration patterns of subventricular zone cells in adult mice change after cerebral cortex injury. Brain Res 996:213-226, 2004

35. Gorostiza P, Volgraf M, Numano R, Szobota S, Trauner D, Isacoff EY: Mechanisms of photoswitch conjugation and light activation of an ionotropic glutamate receptor. Proc Natl Acad Sci U S A 104: 10865-10870, 2007

36. Gradinaru V, Mogri M, Thompson KR, Henderson JM, Deisseroth K: Optical deconstruction of parkinsonian neural circuitry. Science 324:354-359, 2009

37. Grefkes C, Fink GR: Connectivity-based approaches in stroke and recovery of function. Lancet Neurol 13:206216,2014

38. Guenthner CJ, Miyamichi K, Yang HH, Heller HC, Luo L: Permanent genetic access to transiently active neurons via TRAP: targeted recombination in active populations. Neuron 78:773-784, 2013

39. Gunaydin LA, Yizhar O, Berndt A, Sohal VS, Deisseroth K, Hegemann P: Ultrafast optogenetic control. Nat Neurosci 13:387-392, 2010

40. Guo Z, Zhang L, Wu Z, Chen Y, Wang F, Chen G: In vivo direct reprogramming of reactive glial cells into functional neurons after brain injury and in an Alzheimer's disease model. Cell Stem Cell 14:188-202, 2014

41. Han X, Qian X, Bernstein JG, Zhou HH, Franzesi GT, Stern $P$, et al: Millisecond-timescale optical control of neural dynamics in the nonhuman primate brain. Neuron 62:191198, 2009

42. Hao L, Zou Z, Tian H, Zhang Y, Zhou H, Liu L: Stem cell-based therapies for ischemic stroke. BioMed Res Int 2014:468748, 2014

43. Hiu T, Farzampour Z, Paz JT, Wang EH, Badgely C, Olson A, et al: Enhanced phasic GABA inhibition during the repair phase of stroke: a novel therapeutic target. Brain 139:468-480, 2015

44. Horie N, Pereira MP, Niizuma K, Sun G, Keren-Gill H, Encarnacion A, et al: Transplanted stem cell-secreted vascular endothelial growth factor effects poststroke recovery, inflammation, and vascular repair. Stem Cells 29:274-285, 2011

45. Hummel F, Cohen LG: Improvement of motor function with noninvasive cortical stimulation in a patient with chronic stroke. Neurorehabil Neural Repair 19:14-19, 2005
46. Inoue K, Takada M, Matsumoto M: Neuronal and behavioural modulations by pathway-selective optogenetic stimulation of the primate oculomotor system. Nat Commun 6: 8378,2015

47. Jiang W, Xia F, Han J, Wang J: Patterns of Nogo-A, NgR, and RhoA expression in the brain tissues of rats with focal cerebral infarction. Transl Res 154:40-48, 2009

48. Kandori H: Ion-pumping microbial rhodopsins. Front Mol Biosci 2:52, 2015

49. Kawashima T, Okuno H, Bito $\mathrm{H}$ : A new era for functional labeling of neurons: activity-dependent promoters have come of age. Front Neural Circuits 8:37, 2014

50. Kelly S, Bliss TM, Shah AK, Sun GH, Ma M, Foo WC, et al: Transplanted human fetal neural stem cells survive, migrate, and differentiate in ischemic rat cerebral cortex. Proc Natl Acad Sci U S A 101:11839-11844, 2004

51. Kim TI, McCall JG, Jung YH, Huang X, Siuda ER, Li Y, et al: Injectable, cellular-scale optoelectronics with applications for wireless optogenetics. Science 340:211-216, 2013

52. Kozlowski DA, James DC, Schallert T: Use-dependent exaggeration of neuronal injury after unilateral sensorimotor cortex lesions. J Neurosci 16:4776-4786, 1996

53. Krakauer JW, Carmichael ST, Corbett D, Wittenberg GF: Getting neurorehabilitation right: what can be learned from animal models? Neurorehabil Neural Repair 26:923-931, 2012

54. Kügler S, Kilic E, Bähr M: Human synapsin 1 gene promoter confers highly neuron-specific long-term transgene expression from an adenoviral vector in the adult rat brain depending on the transduced area. Gene Ther 10:337-347, 2003

55. Lawlor PA, Bland RJ, Mouravlev A, Young D, During MJ: Efficient gene delivery and selective transduction of glial cells in the mammalian brain by AAV serotypes isolated from nonhuman primates. Mol Ther 17:1692-1702, 2009

56. Lee HM, Giguere PM, Roth BL: DREADDs: novel tools for drug discovery and development. Drug Discov Today 19:469-473, 2014

57. Lee Y, Messing A, Su M, Brenner M: GFAP promoter elements required for region-specific and astrocyte-specific expression. Glia 56:481-493, 2008

58. Levitz J, Pantoja C, Gaub B, Janovjak H, Reiner A, Hoagland A, et al: Optical control of metabotropic glutamate receptors. Nat Neurosci 16:507-516, 2013

59. Levy SL, White JJ, Sillitoe RV: Wheat germ agglutinin (WGA) tracing: a classic approach for unraveling neural circuitry, in Arenkiel BR (ed): Neural Tracing Methods: Tacing Neurons and Their Connections. New York: Spinger, Vol 92, 2015, pp 51-66

60. Li S, Nie EH, Yin Y, Benowitz LI, Tung S, Vinters HV, et al: GDF10 is a signal for axonal sprouting and functional recovery after stroke. Nat Neurosci 18:1737-1745, 2015

61. Li S, Overman JJ, Katsman D, Kozlov SV, Donnelly CJ, Twiss JL, et al: An age-related sprouting transcriptome provides molecular control of axonal sprouting after stroke. Nat Neurosci 13:1496-1504, 2010

62. Luhmann HJ: Ischemia and lesion induced imbalances in cortical function. Prog Neurobiol 48:131-166, 1996

63. Majid A: Neuroprotection in stroke: past, present, and future. ISRN Neurol 2014:515716, 2014

64. McIsaac RS, Bedbrook CN, Arnold FH: Recent advances in engineering microbial rhodopsins for optogenetics. Curr Opin Struct Biol 33:8-15, 2015

65. Mohajerani MH, Aminoltejari K, Murphy TH: Targeted mini-strokes produce changes in interhemispheric sensory signal processing that are indicative of disinhibition within minutes. Proc Natl Acad Sci U S A 108:E183-E191, 2011

66. Mohanty SK, Lakshminarayananan V: Optical techniques in optogenetics. J Mod Opt 62:949-970, 2015 
67. Mozaffarian D, Benjamin EJ, Go AS, Arnett DK, Blaha MJ, Cushman M, et al: Heart disease and stroke statistics - 2015 update: a report from the American Heart Association. Circulation 131:e29-e322, 2015

68. Murphy TH, Corbett D: Plasticity during stroke recovery: from synapse to behaviour. Nat Rev Neurosci 10:861-872, 2009

69. Nagel G, Brauner M, Liewald JF, Adeishvili N, Bamberg E, Gottschalk A: Light activation of channelrhodopsin-2 in excitable cells of Caenorhabditis elegans triggers rapid behavioral responses. Curr Biol 15:2279-2284, 2005

70. Nagel G, Szellas T, Huhn W, Kateriya S, Adeishvili N, Berthold P, et al: Channelrhodopsin-2, a directly light-gated cation-selective membrane channel. Proc Natl Acad Sci U S A 100: 13940-13945, 2003

71. Neumann-Haefelin T, Hagemann G, Witte OW: Cellular correlates of neuronal hyperexcitability in the vicinity of photochemically induced cortical infarcts in rats in vitro. Neurosci Lett 193:101-104, 1995

72. Nowak DA, Grefkes C, Ameli M, Fink GR: Interhemispheric competition after stroke: brain stimulation to enhance recovery of function of the affected hand. Neurorehabil Neural Repair 23:641-656, 2009

73. Oh MS, Hong SJ, Huh Y, Kim KS: Expression of transgenes in midbrain dopamine neurons using the tyrosine hydroxylase promoter. Gene Ther 16:437-440, 2009

74. Ohab JJ, Carmichael ST: Poststroke neurogenesis: emerging principles of migration and localization of immature neurons. Neuroscientist 14:369-380, 2008

75. Ohab JJ, Fleming S, Blesch A, Carmichael ST: A neurovascular niche for neurogenesis after stroke. J Neurosci 26:13007-13016, 2006

76. Orban PC, Chui D, Marth JD: Tissue- and site-specific DNA recombination in transgenic mice. Proc Natl Acad Sci U S A 89:6861-6865, 1992

77. Overman JJ, Carmichael ST: Plasticity in the injured brain: more than molecules matter. Neuroscientist 20:15-28, 2014

78. Park SI, Brenner DS, Shin G, Morgan CD, Copits BA, Chung HU, et al: Soft, stretchable, fully implantable miniaturized optoelectronic systems for wireless optogenetics. Nat Biotechnol 33:1280-1286, 2015

79. Qü M, Mittmann T, Luhmann HJ, Schleicher A, Zilles K: Long-term changes of ionotropic glutamate and GABA receptors after unilateral permanent focal cerebral ischemia in the mouse brain. Neuroscience 85:29-43, 1998

80. Reiner A, Isacoff EY: Photoswitching of cell surface receptors using tethered ligands. Methods Mol Biol 1148:45-68, 2014

81. Risedal A, Zeng J, Johansson BB: Early training may exacerbate brain damage after focal brain ischemia in the rat. $\mathbf{J}$ Cereb Blood Flow Metab 19:997-1003, 1999

82. Rogan SC, Roth BL: Remote control of neuronal signaling. Pharmacol Rev 63:291-315, 2011

83. Rongo C, Kaplan JM: CaMKII regulates the density of central glutamatergic synapses in vivo. Nature 402:195-199, 1999

84. Savitz SI, Cramer SC, Wechsler L: Stem cells as an emerging paradigm in stroke 3 : enhancing the development of clinical trials. Stroke 45:634-639, 2014

85. Schiene K, Bruehl C, Zilles K, Qü M, Hagemann G, Kraemer M, et al: Neuronal hyperexcitability and reduction of GABAA-receptor expression in the surround of cerebral photothrombosis. J Cereb Blood Flow Metab 16:906-914, 1996

86. Schmidt S, Bruehl C, Frahm C, Redecker C, Witte OW: Age dependence of excitatory-inhibitory balance following stroke. Neurobiol Aging 33:1356-1363, 2012

87. Shimizu T, Hosaki A, Hino T, Sato M, Komori T, Hirai S, et al: Motor cortical disinhibition in the unaffected hemisphere after unilateral cortical stroke. Brain 125:1896-1907, 2002
88. Simonelli F, Maguire AM, Testa F, Pierce EA, Mingozzi F, Bennicelli JL, et al: Gene therapy for Leber's congenital amaurosis is safe and effective through 1.5 years after vector administration. Mol Ther 18:643-650, 2010

89. Tsai SY, Markus TM, Andrews EM, Cheatwood JL, Emerick AJ, Mir AK, et al: Intrathecal treatment with antiNogo-A antibody improves functional recovery in adult rats after stroke. Exp Brain Res 182:261-266, 2007

90. Tsai SY, Papadopoulos CM, Schwab ME, Kartje GL: Delayed anti-Nogo-A therapy improves function after chronic stroke in adult rats. Stroke 42:186-190, 2011

91. Tsubota T, Ohashi Y, Tamura K, Sato A, Miyashita Y: Optogenetic manipulation of cerebellar Purkinje cell activity in vivo. PLoS One 6:e22400, 2011

92. Vardy E, Robinson JE, Li C, Olsen RH, DiBerto JF, Giguere PM, et al: A new DREADD facilitates the multiplexed chemogenetic interrogation of behavior. Neuron 86:936-946, 2015

93. Vazey EM, Aston-Jones G: New tricks for old dogmas: optogenetic and designer receptor insights for Parkinson's disease. Brain Res 1511:153-163, 2013

94. Wahl AS, Omlor W, Rubio JC, Chen JL, Zheng H, Schröter A, et al: Neuronal repair. Asynchronous therapy restores motor control by rewiring of the rat corticospinal tract after stroke. Science 344:1250-1255, 2014

95. Waschuk SA, Bezerra AG Jr, Shi L, Brown LS: Leptosphaeria rhodopsin: bacteriorhodopsin-like proton pump from a eukaryote. Proc Natl Acad Sci U S A 102:6879_ 6883,2005

96. Webster BR, Celnik PA, Cohen LG: Noninvasive brain stimulation in stroke rehabilitation. NeuroRx 3:471-481, 2006

97. Weick JP, Johnson MA, Skroch SP, Williams JC, Deisseroth $\mathrm{K}$, Zhang SC: Functional control of transplantable human ESC-derived neurons via optogenetic targeting. Stem Cells 28:2008-2016, 2010

98. Whittle AJ, Walsh J, de Lecea L: Light and chemical control of neuronal circuits: possible applications in neurotherapy. Expert Rev Neurother 14:1007-1017, 2014

99. Wiessner C, Bareyre FM, Allegrini PR, Mir AK, Frentzel S, Zurini M, et al: Anti-Nogo-A antibody infusion 24 hours after experimental stroke improved behavioral outcome and corticospinal plasticity in normotensive and spontaneously hypertensive rats. J Cereb Blood Flow Metab 23:154-165, 2003

100. Williams JC, Denison T: From optogenetic technologies to neuromodulation therapies. Sci Transl Med 5:177ps6, 2013

101. Xerri C, Zennou-Azogui Y, Sadlaoud K, Sauvajon D: Interplay between intra- and interhemispheric remodeling of neural networks as a substrate of functional recovery after stroke: adaptive versus maladaptive reorganization. Neuroscience 283:178-201, 2014

102. Yizhar O, Fenno LE, Davidson TJ, Mogri M, Deisseroth K: Optogenetics in neural systems. Neuron 71:9-34, 2011

103. Zhang F, Wang LP, Boyden ES, Deisseroth K: Channelrhodopsin-2 and optical control of excitable cells Nat Methods 3:785-792, 2006

104. Zhang F, Wang LP, Brauner M, Liewald JF, Kay K, Watzke $\mathrm{N}$, et al: Multimodal fast optical interrogation of neural circuitry. Nature 446:633-639, 2007

105. Zhang S, Boyd J, Delaney K, Murphy TH: Rapid reversible changes in dendritic spine structure in vivo gated by the degree of ischemia. J Neurosci 25:5333-5338, 2005

106. Zhao S, Ting JT, Atallah HE, Qiu L, Tan J, Gloss B, et al: Cell type-specific channelrhodopsin-2 transgenic mice for optogenetic dissection of neural circuitry function. Nat Methods 8:745-752, 2011

107. Zivin JA: Acute stroke therapy with tissue plasminogen activator (tPA) since it was approved by the U.S. Food and Drug Administration (FDA). Ann Neurol 66:6-10, 2009 


\section{Disclosures}

The authors report no conflict of interest concerning the materials or methods used in this study or the findings specified in this paper.

\section{Author Contributions}

Conception and design: Steinberg, Pendharkar, Levy, Ho, Sussman. Acquisition of data: Steinberg, Pendharkar, Levy, Cheng.

Analysis and interpretation of data: all authors. Drafting the article: all authors. Critically revising the article: all authors. Reviewed submitted version of manuscript: all authors. Approved the final version of the manuscript on behalf of all authors: Steinberg. Administrative/technical/material support: all authors. Study supervision: Steinberg, Cheng.

\section{Correspondence}

Gary K. Steinberg, Department of Neurosurgery, 300 Pasteur Dr., R281, Stanford, CA 94305-5327. email: gsteinberg@stanford.edu. 